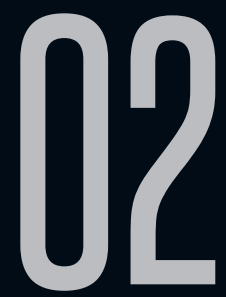

\title{
THE FALL OF EVE: THE FRAILTY OF MORAL ALIGNMENT IN KILLING EVE
}

\author{
Eduarda De Carli (UFRGS) \\ Elaine Barros Indrusiak (UFRGS)
}

Recebido em 05 jan 2020. Eduarda De Carli é Doutoranda em Estudos Literários Aprovado em 19 jun 2020. pela UFRGS.

Email: eduarda.carli@ufrgs.br

ORCID iD: https://orcid.org/0000-0003-4733-6305

Elaine Barros Indrusiak é Professora Associada do Departamento de Línguas Modernas e Professora Permanente do Programa de Pós-Graduação em Letras da Universidade Federal do Rio Grande do Sul. Possui Graduação em Letras - Língua Inglesa (1998), Mestrado (2001) e Doutorado (2009) em Letras - Literatura Comparada pela Universidade Federal do Rio Grande do Sul. É tradutora pública e intérprete comercial do RS e pesquisadora do Núcleo de Estudos de Tradução Olga Fedossejeva (UFRGS) e do grupo de pesquisa Intermídia (UFMG). Realizou Pós-Doutorado junto ao Departamento de Cinema e Mídias Interativas da University of Miami (20152016). Tem experiência de ensino e gestão na área de Letras, atuando principalmente nos seguintes temas: estudos de adaptação e intermidialidade, estudos de narrativa, literaturas e culturas de língua inglesa, estudos de tradução e literatura comparada.

ORCID iD: https://orcid.org/0000-0002-0297-2554 
Abstract: The figure of the double (FREUD, 1955) is recurrent in investigative stories, as the very core of these works is the opposition between detective and criminal. We can read the criminal as the double of the detective in the classic detective genre; their mirror-image of dubious moral and evil acts (KEKES, 2010). As the genre evolved alongside changes in social order, this good-and-evil duality has become more blurred, culminating in the emergence of the hardboiled detective and the noir novel and their future influences. One of the works influenced by the blurring of the tenuous line between good and evil is Killing Eve (BBC America, 2018-), which presents an investigator and an assassin that have a mutual obsession. The aim of this article is to analyze Villanelle, the assassin, as the double image of Eve, the investigator, and how this mirroring results in a change of morality for Eve that represents her descent into evil actions in the first season. Considering the television series as a serialized medium product, we intend to show how a character development as a double entity throughout the series results in changes of alignment in the diegesis.

Keywords: Double; Evil; Killing Eve; Morality; Television Series.

Resumo: A figura do duplo (FREUD, 1955) é recorrente nas histórias de investigação, já que o núcleo dessas obras é a oposição entre detetive e criminoso. Podemos interpretar o criminoso como o duplo do detetive no gênero clássico de detective; sua imagem espelhada de moral duvidosa e ações más (KEKES, 2010). À medida que o gênero evoluiu juntamente com mudanças na ordem social, essa dualidade do bem e do mal se tornou mais confusa, culminando no surgimento do detetive hardboiled e do romance noir e de suas influências. Uma das obras influenciadas pelo embaçamento da linha tênue entre o bem e o mal é Killing Eve (BBC America, 2018-), 
que apresenta uma investigadora e uma assassina que têm uma obsessão mútua. O objetivo deste artigo é analisar Villanelle, a assassina, como o duplo de Eve, a investigadora, e como esse espelhamento resulta em uma mudança de moralidade para Eve que representa sua queda moral na primeira temporada. Considerando a série televisiva como produto de mídia serializado, pretendemos mostrar como o desenvolvimento de um personagem como duplo ao longo da série pode resultar em mudanças de alinhamento na diegese.

Palavras-chave: Duplo; Killing Eve; Mal; Moralidade; Série Televisiva.

\section{INTRODUCTION}

Killing Eve is a series produced by BBC America and BBC One that started airing in 2018, created by Emmy Award-winner Phoebe Waller-Bridge. It currently has two seasons with eight episodes each, and it has been renewed for a third one. The series follows Eve Polastri, portrayed by Sandra Oh, an agent for the British Intelligence who is in charge of pursuing an assassin known as Villanelle, portrayed by Jodie Comer. Eve starts as an MI5 agent whose interests are female assassins, their modi operandi, and their psychology. She is fired from MI5 but is soon recruited by Fiona Shaw (Carolyn Martens), the head of a secret MI6 division that gives her the opportunity and resources for chasing an international skilled assassin, Villanelle, whose real name we will later discover is Oksana Astankova. As the investigations advance, Eve and Villanelle become obsessed with each other; the initial tension of the investigative pursuit becomes a tension of a sexual nature, and Eve becomes desperate in her search for the assassin. 
The series then presents to the viewer the crimes committed by Villanelle and the MI6's attempts at investigating them. Differently from classic procedural series such as CSI and NCIS, which usually meet the whodunit standards, that is, cases in which they must find out the criminal's identity, Killing Eve shows us the perpetrator from the start with her motive - money, as Villanelle is a paid assassin. Up to this point in the expanded narrative arc of the series, we cannot tell who exactly is hiring her, we only know the name of the group, "The 12", and we are also in the dark about the big picture of their plans. This, however, is only secondary to Eve's chase of Villanelle and their mutual fixation. Working for the MI6, Eve has the technology, assets, and the qualified team that she needs to find the assassin, but as she becomes more deeply involved in the investigation, her already strained marriage to Niko Polastri starts to crumble, while she feels increasingly drawn to Villanelle. But to consider Eve's descent, it is important that we first think about the relationship between morality and mystery/investigative fiction, because it is something that has changed over the years since Edgar Allan Poe set the model for the contemporary detective in the first half of the nineteenth century.

Poe inaugurated the genre, as we know it today, with Auguste Dupin, the intellectual detective in "The Murders in the Rue Morgue" (1841) who reappears in "The Mystery of Marie Rogêt" (1842) and later on in "The Purloined Letter" (1844). These three short stories paved the way for the classic detective novel, which appeared in the second half of the nineteen century and went up to the 1930s mostly in Britain with names such as Sir Arthur Conan Doyle and Agatha Christie, the Queen of Crime. These paradigmatic novels 
establish the general moral differences between the detectives and the perpetrators; the detective is on the side of the law - even if their methods may not be approved by the police - and their objective is to restore the order in a society disrupted by crime. In this Golden Age of detective novels, the society in question is a microcosmos, a representation of a larger (British) society that needs to be in proper order, and the detectives are the ones who help maintain this status quo, whether as part of the police force or as private detectives, professionals or amateurs.

In the United States, in the aftermath of the Prohibition and the Great Depression, authors such as Raymond Chandler and Dashiell Hammett presented a new type of investigator as a reaction to those events and their dire effects: the hardboiled detective. This new fiction also reflected the corruption of both organized crime and legal institutions, so this new social order presented characters that cynically questioned the law in their pursuit of justice. Alongside the hardboiled genre, the noir novel also emerged. In the noir novel, however, characters were of a morally dubious nature; protagonists were not necessarily detectives, and the lines between right and wrong, good and evil, moral and immoral were tenuous and constantly blurred. Noir fiction inaugurated a world with no clear right or wrong, and the black and white mode of thinking and pursuing justice gives way to shades of grey. Killing Eve explores this shady behavior in a way that goes with the trend first set by the so-called hardboiled novels back in the middle of the twentieth century in the United States.

The aim of this article then is to analyze the presence of the double in the first season of the television series through the 
characters of Eve Polastri and Villanelle, in order to emphasize how mirror images are important to mystery, detective, and investigative works. Furthermore, a closer look at Eve will allow us to analyze the gradual shift in her moral alignment and an increase in morally dubious actions that verge on evil. In what follows, a brief discussion on the double and other elements concerning evil actions sets the theoretical framework for the case study. Next, the analysis of Eve, Villanelle and their mutual obsession reinforces the idea of the doppelgänger and the interdependency of the characters, which ushers Eve's moral descent. The final part of this article focuses on the moral shift experienced by the main character, who is supposed to be on the side of the law.

\section{ABOUT CHARACTERS IN TELEVISION AND THE FIGURE OF THE DOUBLE}

To begin our theoretical discussion, it is important that we make some considerations regarding the audiovisual product that is our object in this article. In opposition to films, (most) television series are works that are not finite within the time limit of two and a half hours; they are, as the name of the genre already states, serialized works, and as such, we need to consider their extended narrative arcs (MITTELL, 2015). We could of course focus on one or two episodes for a close watching analysis, but because the purpose of this article is to look at the development of Eve Polastri's morality and her relationship with her double, Villanelle, throughout the series, we will not focus on one episode in particular. Since the series is an ongoing project, however, the development of the characters may be completely altered in 
future episodes. Therefore, the analysis herein is provisional and limited to the two first seasons; our findings will have to be put to test as the series progresses.

The title of this article, considering moral alignment to be frail, has a double entendre. First, it refers to the protagonist's own morals in the diegesis and the events that can - and actually do - make her falter. The second meaning refers to the relationship the viewer has with the characters in a television series, because they can be considered one of the most important features of these audiovisual products (SEABRA, 2016). Jason Mittell (2015) proposes that the viewer establishes a relationship with the characters that is threefold: we relate to them in practices of recognition, alignment, and allegiance. We recognize and differentiate characters from inhuman counterparts; then we form an attachment according to how close we are to each character episode by episode, that is, when we follow their adventures, for lack of a better word, and get to know their interior states, emotions, and moral standards; and, at last, we form an allegiance with them as we are aligned and sympathetic to their beliefs and morals (MITTELL, 2015).

But how do we get to know these characters? According to Roberta Pearson (2007), we understand and learn about them by the unveiling of their psychological traits, habitual behaviors, appearances, speech patterns, interactions with other characters (or constellations), their environment, and their biographies. And because we are talking about a serialized work, the first episode, usually referred to as the "pilot", is the one that establishes the initial relevant characteristics that the viewer needs to know, and then, as the series progresses, our own understanding of them is 
either altered or reinforced according to the accumulation of traits and features (MITTELL, 2015).

One of the features that Killing Eve introduces in its early episodes is the dual and interdependent nature of the main characters, which brings to mind the classic motif of the doppelgänger, a recurrent literary trope singled out by Freud in his seminal analysis of the unheimlich, or uncanny, and the mirror image that the double represents. This is particularly relevant here because the idea of the double in investigative stories is not new; in fact, detectives in the stories only exist because there is an opposing force that threatens the world order. There would be no investigator without a perpetrator. As previously mentioned, in the classic detective novel, they are usually on opposite sides of the law; however, since the emergence of the hardboiled genre and the noir novel, the moral line that used to differentiate these mirror images has become blurred. According to Freud,

we have characters who are considered to be identical because they look alike. This relation is accentuated by mental processes leaping from one of these characters to another [...] so that the one possesses knowledge, feelings and experience in common with the other. Or it is marked by the fact that the subject identifies himself with someone else [...]. [...] and finally there is the constant recurrence of the same thing - the repetition of the same features or character-traits or vicissitudes, of the same crimes [...]. (1955, p.234)

To sum up the characteristics of the double, the two individuals may be identical in appearance (which is not always the case, especially when we are looking at detective stories), they can have 
a telepathic bond which forces the one to act according to the other's desires, they may identify with someone else, and there is also a repetition of traits or events that connect them; one's double is someone who is uncanny, that is, someone familiar and unfamiliar at the same time. The double of a character is often shown as an opposite in morality, sometimes with evil intentions, and quite frequently it "[...] become(s) the uncanny harbinger of death" (FREUD, 1955, p.235). Furthermore,

Jung defined the double as an archetype of the collective unconscious, [...] distinct from the self, [...]. Building on Freud, Jung also developed the idea of the shadow of the unconscious, which represents hidden and repressed aspects of a protagonist's personality, or indeed, undeveloped or unlived aspects of his or her life or personality. (MARKLEY, 2001, p.16)

The main distinction between the detective and the perpetrator as their double would be that the criminal lets go of the repressed desires and acts on them, while the investigator does not, maintaining their moral opposition. The line can be blurry as the investigator proceeds with the case, but to maintain the moral distinction between the characters, it is vital that they do not cross to the opposite side. According to John Kekes, we have both benevolent and malevolent motives within us; however, in the context of civilized societies,

we are constrained by moral limits, by commitment to the well-being of others, and by benevolent motives, which we have alongside malevolent ones. If these constraints are effective, they stop us from acting on malevolent motives, but they 
do not stop us from having them. They remain as possibilities, on which we may act, if we face serious hardships, provocations, or temptations. (2010, p.134)

Kekes proposes a focus on evil actions instead of just evil in general; according to him, "An action is evil, then, if (1) it causes grievous harm to (2) innocent victims, and it is (3) deliberate, (4) malevolently motivated, and (5) morally unjustifiable" (2010, p.117). To be able to consider someone as evil, it is only "[...] if their habitual actions are evil and there is no pattern of good actions that may counterbalance the evil ones" (KEKES, 2010, p.118). With this focus, it is also possible to establish that

actions, people, and social conditions can be more or less evil, and evil actions may shade into morally bad actions, because the grievousness of the harm, the innocence of the victims, the malevolence of motivation, the deliberateness and moral justifiability of their performance are often matters of degree about which reasonable and morally committed people can disagree. (KEKES, 2010, p.118)

According to this, in answering the five statements in the proposal for the evil action, we can attempt to identify a degree to which an action could be just bad or evil. In order to discuss the proposed idea of moral frailty and the fall into evil or bad actions - or not -, we intend to use the five categories (grievous harm, innocence of victim, deliberation, motivation, justification) that Kekes (2010) proposes, as quoted above, applying them to the event that is the catalyst for the change in behavior in Eve, as will be analyzed in the next section, contrasting Eve's actions to Villanelle's. 


\section{THE FALL OF EVE POLASTRI}

Before we begin the analysis, it is important that we make it clear that fictional characters can only be analyzed insofar as there are enough textual elements to draw a psychological profile; with an ongoing series, inferences become even more haphazard and must be limited by the information already presented by the narrative. Our focus for this article will be on season one, because it is there that the characters are initially presented to the viewer and we learn what we need about them. We will, however, mention a scene from the second season, but only to reinforce what viewers have already concluded by themselves in watching the first season, that is, the presentation of Villanelle as a psychopath. But to begin with, we will take a look at the two main characters more closely.

Figure 1 - Sandra Oh as Eve Polastri and Jodie Comer as Villanelle ${ }^{1}$

1 Source: BBC America. 
As the image shows, with regards to their physical appearances, they are indeed very different and have traditionally opposed characteristics. Eve is dark-haired while Villanelle is blonde; Eve has curly hair and Villanelle, straight. An element that is worthy of mention is their nationalities: Eve was born in the USA, and Villanelle was born in Russia, maintaining the usual spy rivalry portrayed in movies and television that was established in the Cold War. In the picture, Eve is wearing a pantsuit, in contrast to Villanelle's black sheer dress, which is exemplary of the types of outfits the characters usually wear. Eve wears mostly sensible and comfortable clothes, in neutral tones; her wardrobe consists of pants and button-down shirts. In opposition, Villanelle, when not in a mission, usually goes for extravagant clothes, usually including sheerness, fur, puffy skirts, or what else her style dictates. At one point in season one, Villanelle steals Eve's suitcase when she is in Germany investigating a recent murder; she is visibly disappointed by Eve's choices, apart from a green scarf which she takes for herself, and sends the suitcase back with expensive designer clothes and a fictional perfume named La Villanelle.

Following the same pattern of opposition, their houses are strikingly different. Eve lives in a two-story house in London, nothing too distinctive about it; but it is a home for her. Villanelle's home when not in hotels for the missions is a spacious apartment in Paris, paid by her employers. Differently from Eve's house, her apartment expresses her luxurious tendencies: two wardrobes, one filled with costumes, wigs, and weapons she uses for her assassinations, and other with her designer clothes; her refrigerator, in opposition to Eve's, which is filled with food and 
Tupperware containers, is filled with several bottles of champagne and apparently nothing else.

BBC America's official Killing Eve website describes Villanelle as having a cold interior that contrasts with her exterior that can portray an image of innocence and even childishness sometimes, besides being an assassin who is reckless, extravagant and without a conscience. Killing is a game for her, and she doesn't care about leaving fingerprints or any other kind of DNA evidence on the scenes. Because the investigators don't have anything of her on record, they don't have the necessary physical evidence that it was her in order to bring her to justice, but they can establish the connection between the killings through the samples and (sometimes) partial fingerprints. Eve is the first investigator to establish that the lack of connection between the modus operandi of each crime is in fact Villanelle's pattern, a fact that adds complexity to the assassin's intentional and apparent recklessness.

Something that might strike the viewer's attention from the very first episode is the fact that Niko Polastri, Eve's husband, is aware that she works for the British government. Carolyn, her bossto-be in the MI6 (in the first episode), states that it is better for Niko to suspect that she's having an affair than working for the British intelligence; however, the character seems to prefer to be honest about her line of work than to lie to her husband about it. He knows about her being fired from the MI5 and being recruited by the MI6; he knows she pursues an international assassin and is aware of the dangers and risks that her job entails, which he isn't always happy about - and is clearly stated by him, but it does not stop her from doing her job or travelling to wherever the investigation leads her. 
She talks to him about her suspect and desire to interrogate the witness that is under the MI5's protection, and he comments on the fact that she might be on the wrong side of the law, considering that she has been acting rogue under the MI5's radar:

\author{
NIKO: How bad have you been? \\ EVE: Really bad. \\ NIKO: You're in the wrong department. \\ EVE: Yes. \\ NIKO: You should've been a spy. \\ EVE: Exactly. Thank you. (Killing Eve, S01E01)
}

She ends up dealing with assassins and spies but does not become a spy herself; yet, her actions as someone who works for the government are questionable; she disobeys orders, does her own research in spite of being told not to, bets on outcomes, etc. She is, however, constrained by the moral limits of society - at least up to a certain point, which will be discussed later -, but even so, her acting as such leads to people being killed by Villanelle. It starts with her protecting a witness to one of Villanelle's murders, or better, her failure to protect the woman. The witness is in a hospital and Eve takes a young Polish boy to help translate what the woman has to say - without authorization or knowledge from her boss but both are brutally murdered in the hospital room while Eve is in the bathroom. It is there that she also encounters Villanelle for the first time, when the assassin is disguised as a hospital nurse who tells her to wear her hair down.

It is interesting to consider the layers of power that permeate the series. At the top, there is the mysterious group known 
only as "The Twelve", and they are responsible for ordering the assassinations that are occurring all over the world. In the middle, there are the handlers of the assassins, and we are able to follow two of them more closely: Konstantin, who has a very close relationship with Villanelle, and Raymond, who becomes her handler in season 2. Then, at the bottom layer, we have the assassins themselves. There is a network of assassins they deploy to commit the killings, but Villanelle is one of the most skilled killers and the Police have no files on her, even with her not wearing gloves or minding leaving evidence behind on crime scenes; there is an arrogance to the character in knowing no one will be able to catch her. We are still unsure about the organization's motives behind all the assassinations, but we do know Villanelle's: money. She lives a luxurious life with the money from her job, and in season two she starts killing for fun as well, besides her paid assassinations. Her actions in season one, then, can be considered evil, and so can she, because of a lack of good deeds on her part to counterbalance.

Eve, however, is meant to pose an opposition to Villanelle. She is the one who is chasing her, investigating the assassinations, and is the first one to actually identify that the lack of pattern in the murders is actually the pattern that they need to follow in order to bring her down. That until the event that triggers her moral downfall. In episode three of the first season, Eve is with Bill Pargrave, a friend and coworker, in Berlin, investigating another assassination. Eve has lost her luggage, and when she is leaving for a dinner with a contact, Bill notices there is a woman following her wearing an item of clothing that was in Eve's suitcase, and the viewer already knows 
it's Villanelle. He stops her from going any further into the train, and when she leaves the station, he starts following her, going to an underground club as their final location for the night. He sends Eve voice messages informing her of what he's doing, and shortly before Eve gets to the club, Villanelle stabs him several times, and he dies in Eve's arms. Bill's death is going to drive Eve's obsession with finding Villanelle even further, now set on getting some kind of revenge for her friend's death.

Before we develop on this, we should take a look at the doubling of the characters. Regarding the mirror images, we must start not by Eve and Villanelle's relationship, but in an earlier diegetic time. In the beginning of the season we see a drawing of a faceless woman with curly hair made by Villanelle, and we learn her name is Anna, but it is not until much later on that we find out Anna was Villanelle's first obsession, when she was still Oksana. Anna was her French teacher, and they developed a close relationship that led to Oksana's first kill: Anna's husband, including his castration. When Villanelle first sees Eve in a bathroom, as previously mentioned, she freezes for a moment, looking at Eve's curly black hair, very similar to that of Anna's. Her obsession with Eve starts then not only because she is the MI6 agent chasing her, but because she looks so similar to her previous lover. Villanelle even seduces a woman and says she's going to call her Eve, attributing it to a biblical fantasy, but the viewer knows better: the woman has dark curly hair.

And we now reach Eve and Villanelle's relationship. They represent opposing sides in moral constraints that are dictated by society; Villanelle acts on her desires without any control or regard for the law or morality, while Eve represses hers, at least 
initially. She is not, however, constructed in a way that her morality is in complete opposition to Villanelle's. Her character has flaws, contradictions, doubts; the viewer follows her struggles and actions throughout the season, having justifications for her actions and the fact that she has enough control of most of her repressed desires helps exempt her from being labeled as evil. This happens, of course, because she is the one to whom the viewer has more access. She starts the series being hired by the MI6, fitting the profile of the "foreigner" character (SEABRA, 2006) who arrives in a new place and must learn the rules and how the system works, just as the viewer starts the series by learning its workings, so she is the one to whom we can relate. Although the viewer has some access to the character and relationships of Villanelle, due to her nature, we do not have much information on her motivations besides the money and her obsession with Eve, so it becomes harder to relate to such a character when on the other hand we have a character whose inner workings we can understand better.

Their initial relationship is that of complete opposition: intelligence agent and assassin, detective and criminal, cat and mouse - although we can question who would be considered the cat and the mouse in this relationship. But from the moment they meet in that bathroom, the mutual obsession becoming stronger, the characters are able to start developing a different, more nuanced, and full of tension relationship. What initially is only professional becomes personal. When Villanelle steals Eve's suitcase, she is able to get her address from it - which Eve's husband insisted on her writing on the back of the luggage - and goes to visit her in London, invading her safe space and turning 
Eve's home, so familiar and safe to her, into a place that she needs to protect and that also becomes the unheimlich, the unsettling. They have a fight while Eve is wearing one of the dresses Villanelle sent her, and when the assassin states she isn't there to kill her, she just wants to talk, they proceed to do so while having shepherd's pie leftovers.

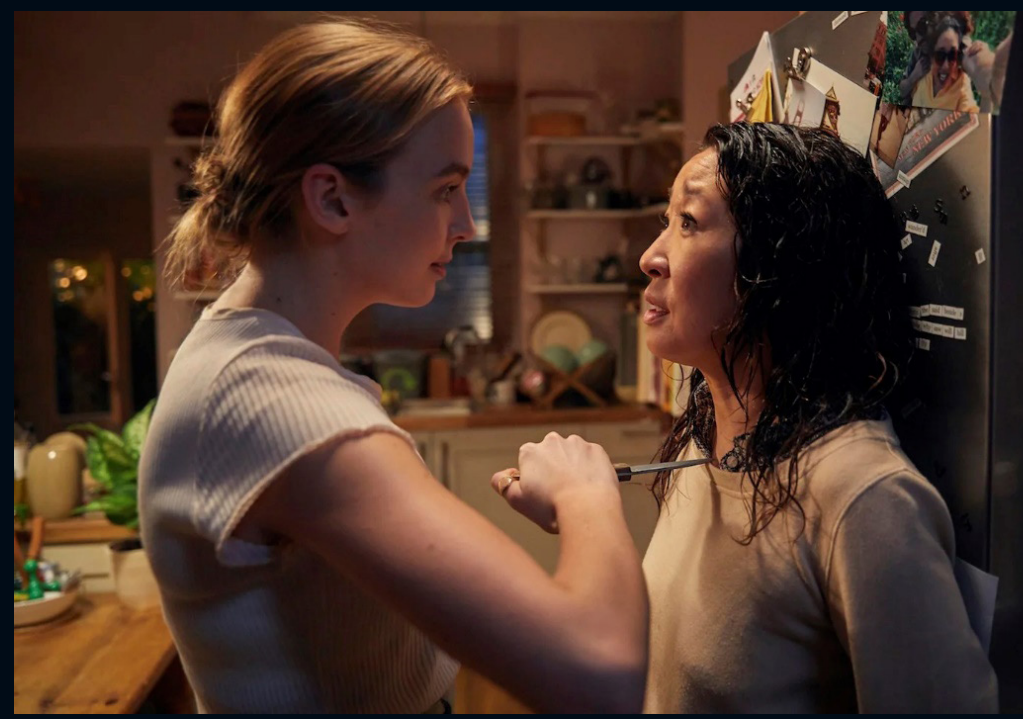

Figure 2 - Villanelle holds a knife against Eve's body²

Interestingly, Villanelle presses Eve against the refrigerator with a knife, and then Eve gets a knife to feel a sense of protection while they sit at the table and talk. It is with a knife that Bill is killed, and with it that Eve stabs Villanelle, even though both could have guns as their weapon of choice. But it is the knife, of course, that is more symbolic of the phallic image between these two female characters; Eve penetrates Villanelle's body with a blade, in turn creating a closer bond between the two of them that is going to be 
strongly developed during season two. But this bond had already been in the workings with their mutual obsession, as we can see in the following dialogue.

EVE: I think about you all the time. I think about what you're wearing and what you're doing and who you're doing it with. I think about what friends you have. I think about what you eat before you work and what shampoo you use and what happened in your family. I think about your eyes and your mouth and what you feel when you kill someone. I think about what you have for breakfast. I just want to know everything.

VILLANELLE: I think about you too. I mean, I masturbate about you a lot. (Killing Eve, S01E08)

Eve's marriage to Niko is presented to the viewer in such a way that we know it is starting to crumble, and her drive for Villanelle only hurts their relationship, because even when she is at home she does not disconnect from her work, because, as stated, the connection between the two characters has become personal, so it actually invades her home even before the assassin does so physically in the fifth episode. The marriage becomes even more strained after Eve starts travelling more in her pursue for Villanelle, and the tension between the two women increases, culminating in the dialogue aforementioned in the first season. Villanelle confesses to masturbating to Eve, and in the second season the viewer is going to be presented with such a scene; the tension between the characters becomes one of a sexual nature; the viewer already knows Villanelle is bisexual, having had a boyfriend and numerous flings with women, but Eve's discovery happens gradually. In a conversation with Bill, she affirms she had never done anything 
or had any thoughts or interest in women, but the obsession and fascination that she has for Villanelle will make her reevaluate her feelings. She even - spoiler alert - kills someone with an axe in order to protect Villanelle and intends to run away with her at the end of season 2, showing how far Eve can go now that she has crossed the line of moral constraints.

With this, it is important that we briefly mention another event from season two, that reinforces the fact that the character's moral alignments and personal construction have been changing. In the fifth episode, Carolyn brings a psychologist to talk to the new MI6's team about the mind and behavior of psychopaths, and he pays close attention to Eve's reactions to what he is saying and showing with the slides to report to the boss. She is the only one not to react to a gruesome picture, while all the others have strong reactions of disgust or even closing their eyes.

MARTIN: [...] Psychopaths are incapable of interpersonal human relationships. The I-You. For a psychopath, there is only I-It. Other people are just objects to them, to be picked up and put down at will. [...] Right, er Superficial charm. Dishonesty. An inability to form lasting intimate relationships. A poverty of emotions. (Killing Eve, S02E05)

At this point, he shows a picture of a bloodied corpse, and all the people in the room gasp, flinch, and avert their eyes, with the exception of Eve, and he discreetly takes notice of that. He continues,

MARTIN: [...] Psychopaths are narcissistic. They're pathologically manipulative. However, they do respond to a certain amount of manipulation. You can't change them, but you can manage them. Money, praise and attention will help for a while. 
But honestly, there's no containing anyone like this for any length of time. (Killing Eve, S02E05)

It is now Eve's turn to avert her eyes. As he is stating these characteristics, and how there is only manipulation, he projects a picture of Villanelle. Everyone in the room looks at the picture with no problems, but Eve can't do so. The thought of their connection not being real but just manipulation on Villanelle's part is not acceptable for her, and her image on the screen is the one that is difficult to look at; it is difficult for her at this moment to confront what it means to their connection that has only grown stronger.

All the events in season one, then, are going to lead to the questioning of the frailty of Eve's morality. On the part of the viewer, the alignment does not seem to change, as we still see most of events from her perspective due to camera choices of focalization. When it comes to her own moral alignment, things are not so clear. In becoming closer and more of a mirror image of Villanelle, being capable of bringing the other's destruction, the moral constraints that prevent her from acting on her repressed desires are going to be played with and even ignored at points. But is that enough to make her, Eve Polastri, MI6 agent, or her actions evil, as proposed by Kekes (2010)? We do not believe so, especially when contrasted to Villanelle's actions.

To emphasize this argument, let us take a moment to consider the event of Bill's death according to the five criteria proposed by Kekes (2010), transforming them into questions. The action here considered is the stabbing of Bill in the middle of the club. First, does it cause grievous harm? Yes, it does. Second, is it to an innocent victim? Yes, it is. Third, is it deliberate? Yes, it is. She chooses to do so 
because he was following her. Fourth, is it malevolently motivated? We could say so, as the scene is very brutal, with Villanelle stabbing him several times. And, at last, fifth, is it morally unjustifiable? Yes, it is, if we take into consideration that the viewer is aligned and has allegiance to Eve Polastri.

Now let's consider the stabbing of Villanelle by Eve at the end of the first season. First, does it cause grievous harm? Yes, it does; Villanelle is severely injured. Second, is it to an innocent victim? No, it is not. Even though it was not a fight, the viewer would not consider Villanelle to be characterized as such. Third, is it deliberate? Yes, it is, or at least it seems to be so. We can see her picking up the knife and hiding it before getting into bed with Villanelle, so even if she went to the apartment on a whim and we see Eve shocked and trying to help Villanelle after the stabbing, as if the action dawned on her, it was still a conscious choice. Fourth, is it malevolently motivated? And fifth, is it morally unjustifiable? The answer to both questions is negative considering our allegiance to the character of Eve. We are shocked by Bill's death and we see Eve struggle with the loss of a friend. We closely follow her as her obsession with Villanelle becomes even stronger after his death and her drive to find her knows no boundaries anymore, making her disobey Carolyn and go after Villanelle by herself. The viewer understands why Eve stabs Villanelle and the act can be justifiable as the revenge for Bill.

When the mutual obsession becomes a fascination and even a form of infatuation on both sides, the characters grow closer and more similar, acting more as doubles, mirror images of each other. And it is due to this that there is a frailty in Eve's moral alignment, 
leading to her moral downfall when acting on temptations and on her repressed desires. Even though we have argued that her actions can be considered bad, but not evil, they are still not morally aligned with the social constraints, fitting what we have titled the fall of Eve.

\section{FINAL CONSIDERATIONS}

In the comparison of the two events in the previous section, it was possible to see that the answers for Villanelle's action were all positive. So indeed, Bill's murder was an evil action and, even more so, there are no deeds on her part to counterbalance. Eve's crime, however, had a mix of answers, but it still had more negatives than affirmatives, which allows us to conclude that it fits into the scale of morally bad actions, instead of being an evil one. Some viewers could even argue that her action was not deliberate, that it was a spur-of-the-moment kind of decision, attenuating even more the branding of evil on it.

With the discussion on the characters' constructions, the doppelgänger and the evilness in their actions, it was possible to see that their mutual obsession allows for a depiction of their relationship as a double and interdependent one, each one becoming the other's harbinger of death. Moreover, the fact that Eve attacks Villanelle strengthens the dubious morality that has been present in the character from the beginning; it is through the full circle of becoming Villanelle's double that she can act on her repressed desires, even if arguably spontaneously. Her actions take her to a moral descent, which is going to lead to changes in her personality, bringing her even closer to Villanelle, and to even more dubious behavior in the second season of the television 
series. What starts as an investigation turns into an obsession that proves the frailty of moral alignments inside and outside the diegesis - the viewer can be shaken by Eve's behavior and choices, but it is through the development of her character and the justifications for her actions that it is possible to still maintain an allegiance to her.

\section{REFERENCES}

BBC AMERICA. "Killing Eve". In http://www.bbcamerica.com/shows/killing-eve/ Access on 2.Jan.2020.

FREUD, Sigmund (1955). "The Uncanny". In: An Infantile Neurosis and Other Works. London: Hogarth Press. p. 217-252.

JUNG, Carl Gustav (1971). The Archetypes and the Collective Unconscious. Princeton: Princeton University Press.

KEKES, John (2010). "The Human Dimension and Evil". In: KEKES, John. The Human Condition. Oxford: Oxford Uuniversity Press. p.114-137.

MARKLEY, A.A (2001). "Mary Shelley's 'New Gothic' - Character Doubling and Social Critique in the Short Fiction". Gothic Studies, Apr. 3(1). In http:// connection.ebscohost.com/c/literary-criticism/4826723/mary-shelleys-newgothic Access on 15.Dec.2019.

MITTELL, Jason (2015). Complex TV: The Poetics of Contemporary Television Storyteling. New York: New York University Press.

PEARSON, Roberta (2007). "Anatomising Gilbert Grissom: The Structure and Function of the Televisual Character". In: ALLEN, Michael (Ed.). Reading CSI: Crime TV Under the Microscope. London: I.B. Tauris.

SEABRA, Rodrigo (2016). Renascença: a série de TV no século XXI. Belo Horizonte: Autêntica Editora. 